\title{
Imaging Findings of Cyst Hydatid Lesions in a Patient with Multiorgan Involvement: A Case of Hydatid Cyst with Multiorgan Involvement
}

\author{
Multiorgan Tutulumu Olan Hastada Kist Hidatik Lezyonlarının Görüntüleme Bulguları \\ Multiorgan Tutulumu Olan Kist Hidatik Olgusu
}

\author{
๑ Pınar Gündoğan Bozdağ, ๑ Ahmet Bozdağ*, ๑ Abdullah Böyük** \\ University of Health Sciences Turkey, Elazığ Fethi Sekin City Hospital, Clinic of Radiology, Elazığ, Turkey \\ ${ }^{*}$ Firat University Faculty of Medicine, Department of General Surgery, Elazığ, Turkey \\ **University of Health Sciences Turkey, Elazığ Fethi Sekin City Hospital, Clinic of General Surgery, Elazığ, Turkey
}

Abstract

Hydatid disease (HD) is a zoonosis caused by the larval form of the Echinococcus granulosus parasites in which human is the intermediate host. Hydatid cysts mainly develop in the liver and lungs. However, they can be found in all anatomical locations, especially in endemic areas. Herein, we present a case of $\mathrm{HD}$ involving the liver, kidney and breast with the findings of mammography, ultrasonography and computed tomography.

Keywords: Hydatid cyst, multiorgan, breast, renal
Öz

Kist Hidatik Hastalığı (KHH), Echinococcus granulosus parazitinin larval formu tarafından oluşturulan insanın ara konak olduğu bir zoonozdur. Sıklıkla karaciğer ve akciğerde lokalize olur. Özellikle endemik bölgelerde, tüm anatomik lokalizasyonlarda bulunabilir. Biz eş zamanlı tanı konulan karaciğer, böbrek ve meme tutulumu olan bir KHH olgusunu mamografi, ultrasonografi ve bilgisayarlı tomografi görüntüleme bulguları ile sunduk.

Anahtar Sözcükler: Kist hidatik, multiorgan, meme, böbrek

\section{Introduction}

Hydatid disease (HD) is a zoonosis caused by the larval form of the Echinococcus granulosus parasites in which human is the intermediate host (1). Hydatid cysts mainly develop in the liver (75\%) and lungs (15\%) and less frequently (10\%) in other internal organs (2). Hydatid cyst of the breast is very rare and patients usually present with painless swelling of the breast. Since it is usually asymptomatic, it is diagnosed during routine mammographic examinations $(2,3)$. Herein, we present a case of HD involving the liver, kidney and breast with findings of mammography (MG), ultrasonography (USG) and computed tomography (CT).

\section{Case}

A 45-year-old woman was referred from the general surgery outpatient clinic to the radiology department for routine breast screening and non-specific abdominal pain. On physical examination, there was no abnormal abdominal examination finding except for a scar of a previous right subcostal incision from a liver hydatid cyst surgery. Breast examination revealed a palpable mobile mass with an elastic consistency in the upper outer quadrant of the left breast. Breast USG examination revealed a heterogeneous hyperechoic lesion (Type 4) of approximately $2 \times 2 \mathrm{~cm}$ in size in the left breast at the 2 o'clock position having smooth borders and a folded thick membrane view inside, with acoustic enhancement (Figure 1). Abdominal USG showed a heterogeneous hyperechoic lesion (Type 4) of approximately $5 \times 3.5$ $\mathrm{cm}$ in size in the upper part of the right kidney which located cortically, had smooth borders and a folded thick membrane view inside and acoustic enhancement. In the segment 4 of the liver, there was a cystic lesion (Type 2)
Address for Correspondence/Yazışma Adresi: Ahmet Bozdağ, Fırat University Faculty of Medicine, Department of General Surgery, Elazığ, Turkey

Phone: +90 5336525163 E-mail: abozdag80@hotmail.com ORCID: orcid.org/0000-0003-1973-2511 Received/Geliş Tarihi: 30 April 2019 Accepted/Kabul Tarihi: 11 March 2020
${ }^{\circ}$ Copyright 2020 by The Medical Bulletin of istanbul Haseki Training and Research Hospital The Medical Bulletin of Haseki published by Galenos Yayınevi. ${ }^{\circledR}$ Telif Hakkı 2020 istanbul Haseki Eğitim ve Araștırma Hastanesi Haseki Tıp Bülteni, Galenos Yayınevi tarafından yayınlanmıştır. 
of approximately $6.5 \times 6 \mathrm{~cm}$ in size with separated thick membrane inside demonstrating acoustic enhancement (Figure 2). The patient had a history of surgery for a hepatic hydatid cyst. When the patient's previous radiological examinations were reviewed, her previous MG showed an opacity measuring approximately $2 \times 2 \mathrm{~cm}$ with smooth borders and lucent folds inside (Figure 3 ) in the left upper quadrant of the left breast. Abdominal CT revealed a thick-walled cystic lesion of $6.5 \times 6 \mathrm{~cm}$ in size with detached thick membrane inside in the segment 4 of the liver. Besides, there was a thick-walled heterogeneous lesion measuring approximately $5 \times 3.5 \mathrm{~cm}$ with smooth borders and folded thick membrane inside in the upper part of the right kidney (Figure 4). Liver function tests and biochemical tests were within the normal limits. Hemagglutination test was negative for HD. Surgical treatment was recommended but the patient refused. Informed consent was obtained from the patient.
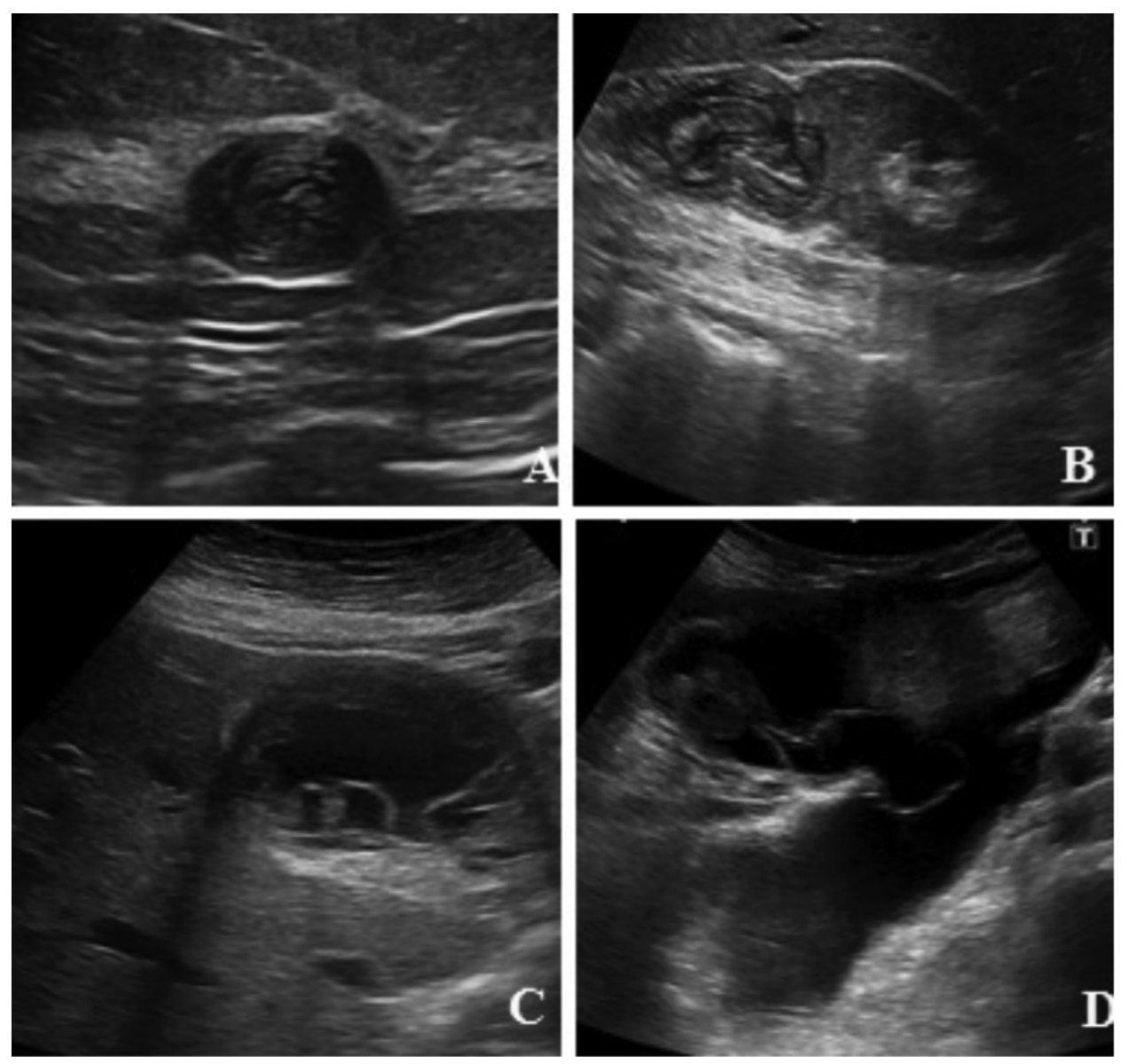

Figure 1. A) Breast US, heterogeneous hypoechoic solid lesion with acoustically strengthened and internal curved hypoechoic membranes in the left breast. B) Abdomen US, heterogeneous solid lesion with smoothly lobulated contours, exophytic extension, acoustic strengthening, internal curved hypoechoic membranes in the lower part of the kidney. C) Multiple septated cystic lesion with acoustic strengthening in the left lobe of the liver. D) Septal fluids in the lower quadrant of the abdomen

US: Ultrasonography 


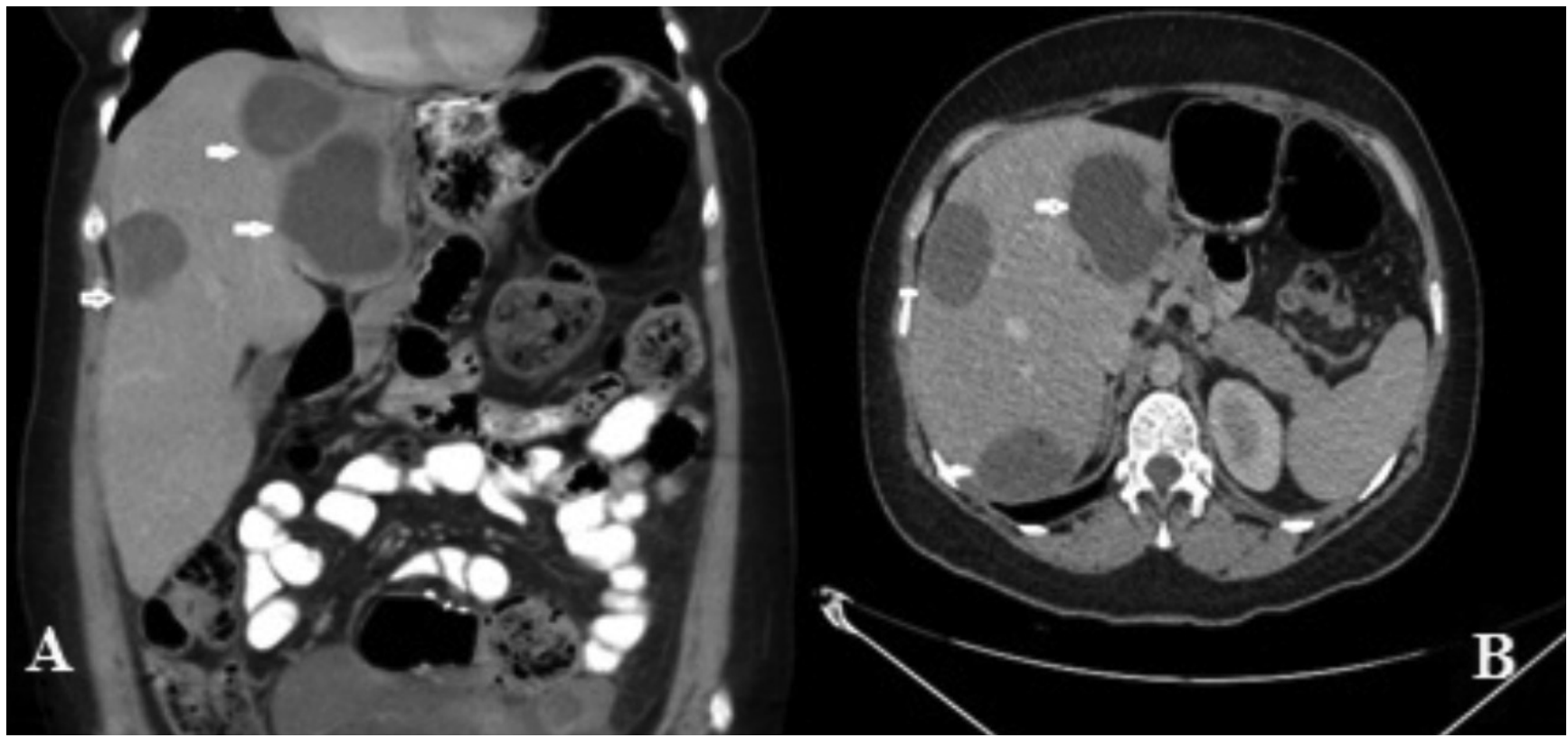

Figure 2. Upper abdomen CT A) Coronal and B) Axial, 3 cystic lesions of hypodense fluid density with smooth limited and internal hyperdense septations in liver

CT: Computed tomography
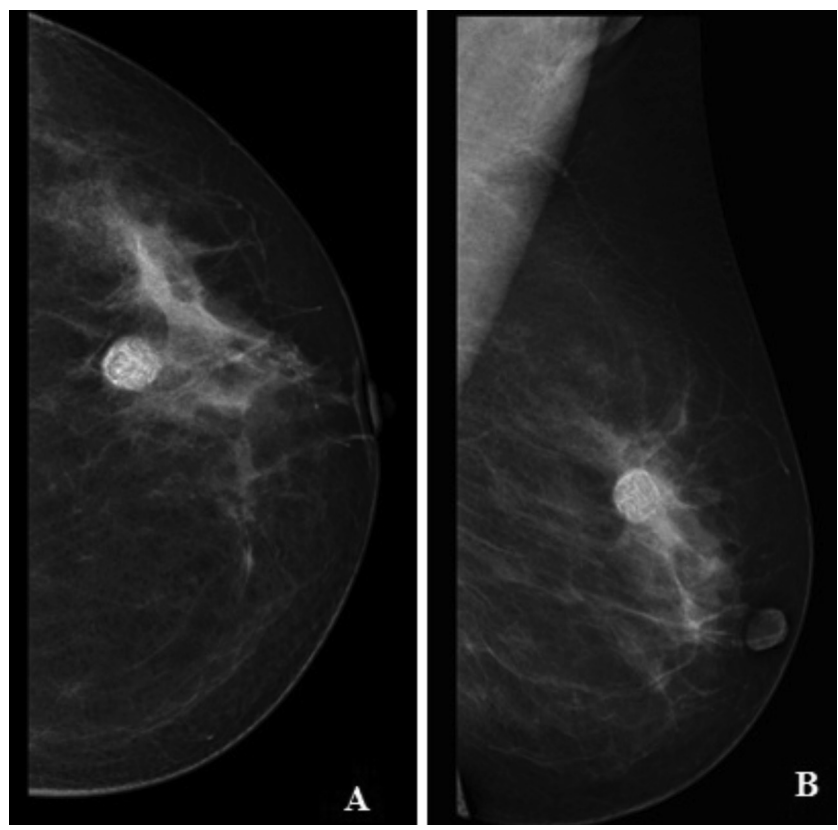

Figure 3. Mammography A) CC and B) MLO, opacity with smooth limited and internal lusen curved areas in the upper outer quadrant of the left breast

CC: Craniocaudal, MLO: Mediolateral oblique

routine screening and the hydatid cyst of the breast was incidentally detected.

Renal involvement is usually associated with systemic involvement, while isolated renal HD is a very rare condition. However, the kidney is the most frequently involved organ in the genitourinary system (6).

USG shows complex cysts in all patients. USG is the primary imaging modality for classification of hydatid cysts. During USG examination, similar to that in other organs, hydatid cysts in the breast are evaluated as well-bordered structures with mixed echo characteristics containing multicystic and solid areas (2). They are difficult to diagnose unless cyst membranes or fluid levels are observed on USG images. On MG, they are demonstrated as homogeneous, non-specific, round lesions with smooth-contours. Annular structures around a radiopaque, well-countered lesion on MG are also indicative of HD. Presence of hydatid cysts in other organs supports the diagnosis of breast $\operatorname{HD}(7,8)$. There was no difficulty in diagnosing breast HD in our patient, because the appearance of the lesion on USG and on the previous MG was typical and she had a medical history of HD.

CT and USG provide similar information. However, CT shows the location and depth of the cyst in the liver more accurately. CT scans show the presence of daughter cysts and exogenous cysts. MRI provides the structural details of the hepatic hydatid cyst. MRI findings are non-specific. Cystic lesions are hyperintense on $\mathrm{T}_{2}$-weighted images and hypointense on $\mathrm{T}_{1}$-weighted images. Contrast MRI shows a cystic lesion with peripheral enhancement $(9,10)$.

The common treatment options are surgical treatment, medical treatment, puncture, aspiration, injection, and re-aspiration. In medical treatment, praziquantel can 


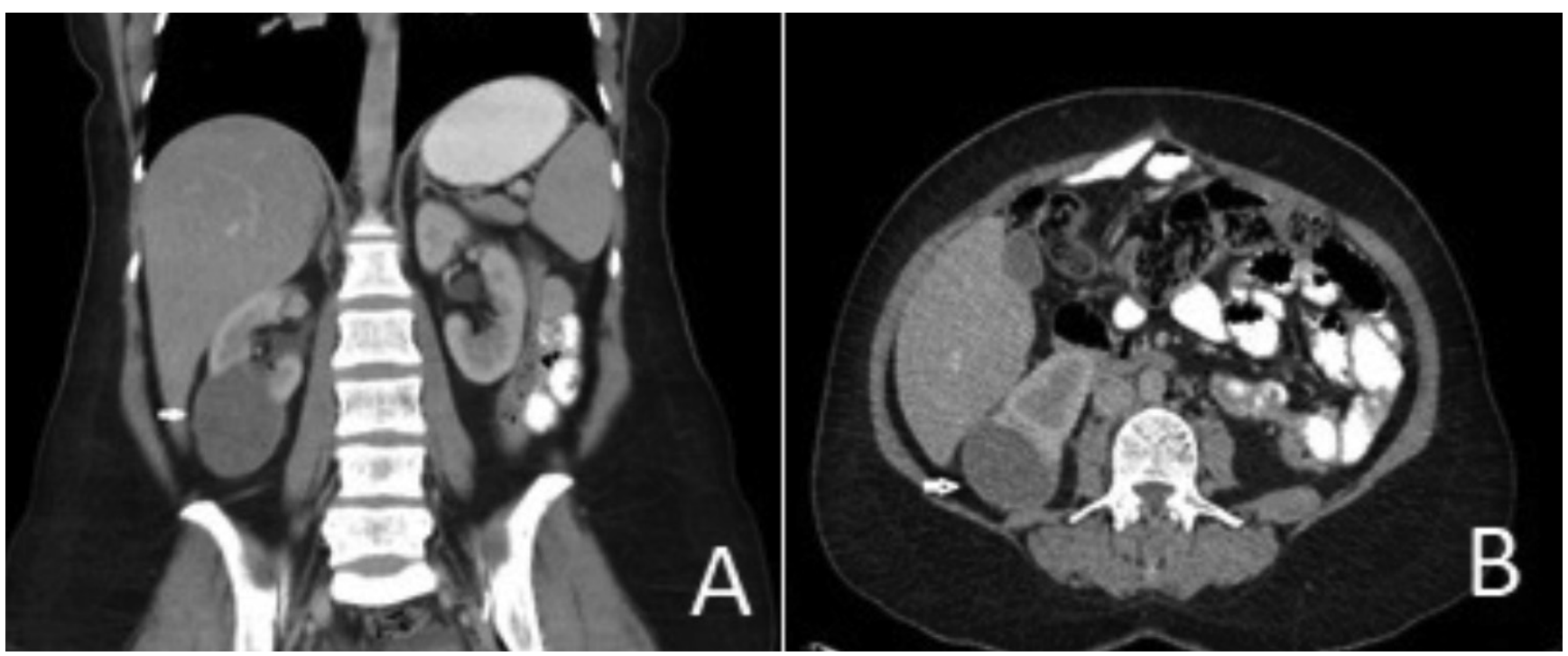

Figure 4. Upper abdomen CT. A) Coronal and B) Axial, cystic lesion in the right kidney with exophytic extension and internal hyperdense septations

CT: Computed tomography

be used with benzimidazoles such as mebendazole and albendazole. Medical treatment with albendazole and mebendazole is carried out prior to and after the surgery to ensure cyst sterilization, to reduce the risk of anaphylaxis and prevent recurrence after surgery.

In conclusion, HD is a serious public health problem in endemic regions. It affects many organs through intraoperative transmission or by hematogenous spread. Breast and renal hydatid cysts are rare; hence, the differential diagnosis is challenging. It should be kept in mind in patients with hepatic HD.

\section{Authorship Contributions}

Concept: P.G.B., A.B. Design: P.G.B., Ab.B. Data Collection or Processing: P.G.B., A.B. Analysis or Interpretation: P.G.B., Ab.B. Literature Search: P.G.B., A.B. Writing: P.G.B., A.B.

Conflict of Interest: No conflict of interest was declared by the authors.

Financial Disclosure: The authors declared that this study received no financial support.

\section{References}

1. Tali S, Aksu A, Bozdağ PG, Bozdağ A. Primary Retroperitoneal Hydatid Cyst. Turkiye Parazitol Derg 2015;39:241-3.
2. Inci $E$, Aydın S, Baysal N, ve ark. İzole primer meme hidatik kisti: Olgu sunumu. Med J Bakirkoy 2006;2:31-2.

3. Koc A, Sarici IS, Vurdem UE, Karabiyik O, Gumus UO. Unusual Presentation of Hydatid Cyst in Breast with Magnetic Resonance Imaging Findings. Case Rep Med 2017;2017:6237435.

4. Dziri C. Hydatid disease - Continuing serious public health problem: introduction. World J Surg 2001;25:1-3.

5. Micu BV, Jeican II, Micu CM, Pop TR. Breast Hydatid Cyst: Case Report. J Bacteriol Parasitol 2017;8:2.

6. Merdin A, Ögür E, Kolak ÇÇ, ve ark. Renal Kist Hidatik. Turkiye Parazitol Derg 2014;38:190-3.

7. Mujawar P, Suryawanshi KH, Nikumbh DB. Cytodiagnosis of isolated primary hydatid cyst of breast masquerading as a breast neoplasm: A rare case report. J Cytol 2015;32:270-2.

8. Malik A, Chandra R, Prasad R, Khanna G, Thukral BB. Imaging appearances of atypical hydatid Cysts. Indian J Radiol Imaging 2016;26:33-9.

9. Gümüş $M$, Gümüş $H$, Budak $H$, Teke $M$. Breast Cyst Hydatid: A Case Report. Ann Clin Cytol Pathol 2016;2:1017.

10. Dagli AF, Ozercan MR, Kocakoc E. Hydatid cyst of the breast mimicking inflammatory carcinoma and mastitis. J Ultrasound Med 2006;25:1353-6. 